\title{
Developing Regional Healthcare Facilities in Maldives through Mudharabah Perpetual Sukuk
}

Fathimath Nashwa Badeeu

Aminath Reesha Nafiz

Aishath Muneeza

\section{International Centre for Education in Islamic Finance (INCEIF)}

\begin{abstract}
The purpose of this paper is to identify the underlying issues of healthcare system in Maldives in order to provide an understanding of the challenges facing healthcare providers in islands and atolls in a wider context. The paper scrutinizes the financial burden faced by the current healthcare system in Maldives. It also proposes shariah compliant mechanism that can be utilized to minimize financial burden in a long-term basis. It is hoped that the outcome of the research will assist the policymakers of Maldives to devise a shariah compliant mechanism to finance the development of atoll and island health facilities in a sustainable manner.
\end{abstract}

Keywords: Maldives; Healthcare Financing; Mudharabah; Perpetual Sukuk; Islamic Finance 


\section{Introduction}

Maldives is a small island nation with a population of around 400,000 residents (including foreigners) as of 2018 (World Bank, 2018). The nation is made up of 1,200 coral islands scattered across the ocean in a chain of twenty-seven atolls. Because of this, it is challenging to provide good healthcare in every islands of the Maldives. Like other countries with multiple small islands, the costs of delivering healthcare in Maldives are high due to geographic dispersion of the inhabited islands and lack of skilled health professionals in rural areas.

There are a number of challenges faced by the government to provide good healthcare. One of them is limited financial resource: the government provides free healthcare to all Maldivians and the healthcare system is mainly funded by the government. As healthcare spending tends to increase over time, healthcare expenditure could consume a significant proportion of public spending each year.

International Financial Facility for Immunisation (IFFIm) issued Vaccine Sukuk in 2014 -- a three year US $\$ 500$ million transaction -- in order to fund humanitarian projects (Vizcaino, 2014). It is the largest debut issue by a global non-profit organisation, and it was warmly received by the markets. A year later, IFFIm issued its second Vaccine Sukuk, and it was oversubscribed by 1.6 times (Bennett, 2015). It is believed that sukuk can be utilised as an alternative model to fund healthcare. This paper intends to propose and conceptualise issuance of sukuk that could help in raising capital and overcoming financial constraints faced by the government.

The objective of the paper is to propose a shariah compliant instrument to resolve the financial challenges faced by the government in providing healthcare facilities. In the course of doing this, we will be looking into the current healthcare system in Maldives, with a focus on the challenges faced by the healthcare system. This paper also aims to offer an alternative mode of financing to fund healthcare using the concepts of perpetual sukuk and Mudharabah.

This paper is structured as follows: it first starts with an overview of Islamic bonds and proceeds with the healthcare system in Maldives. Next, it highlights the financial constraint faced by the healthcare providers in Maldives. Following to that, proposes a shariah compliant instrument to fund healthcare in the country. The present study adds to the existing literature in the area of healthcare financing and Islamic financial structure, especially the application of perpetual sukuk in the context of Maldives. It also offers a new hybrid model to the healthcare providers in Maldives, including both public and private sectors, such that the implementation of the proposed model could inspire them to develop alternative healthcare financing instead of solely relying on existing funding models.

\section{An Overview of Islamic Bonds}

According to the Accounting and Auditing organization for Islamic Financial Institutions (AAOIFI) "sukuk is a certificate of equal value representing undivided shares in ownership of tangible assets, usufruct and services and services (in

International Journal of Management and Applied Research, 2019, Vol. 6, No. 2 
ownership of) the assets of particular projects" (AAOIFI, Shariah Standard (17) on investment Sukuk) In short, sukuk is a freely tradable financial certificate which involves asset ownership. Like bond holders, sukuk holders receive periodic profit payments on the principal amount invested and receive principal amount of investment upon maturity.

Although sukuk is often referred as Islamic bond, it is different from conventional bond due to the following reasons: first, sukuk represents partial ownership of an asset whereas bond is a debt obligation (Ismath Bacha and Mirakhor, 2019). In other words, sukuk is a type of asset-backed financing whereas bond is a form of debt-based financing. Second, the pricing of a bond is based on credit rating or the credit worthiness of the bond issuer; the pricing of a sukuk, on the other hand, is based on market value of underlying assets (Lahsasna et al., 2018). Third, sukuk issuance must be in accordance with shariah law. The nature of the investment, the overall social benefits resulting from the investment, and the way financial rewards and risks are managed are matters of great importance for shariah compliant financial institutions. Prohibition of Riba (interest), Gharar (uncertainty) and Maysir (gambling) are fundamental to Islamic finance and thus Islamic securitization must be free from these elements and it must be backed by assets. Unlike bond holders who receive fixed interest rates payment, sukuk holders receive periodic profit payment come in the form of rental or profit-sharing, which subject to financial losses.

Every Islamic Financial product and transactions have to be based on a shariah compliant contract. The first sukuk was issued in Malaysia by Shell MDS Sdn in the year 1990, based on Bai' Bithaman Ajil (BBA) structure (Ismath Bacha and Mirakhor, 2019). Over the years, many different types of contracts are being used to issue sukuk (equity-based, lease-based, forward sale-based etc.), depending on the project or business the sukuk is financing. Since the issuance of the first sukuk, sukuk market continues to grow steadily. Recent innovative products on the sukuk market include perpetual sukuk, retail sukuk, subordinate sukuk and Sustainable Responsible Investment sukuk. For the purpose of this paper, perpetual sukuk will be further discussed.

Perpetual sukuk is a hybrid sukuk which includes both features of debt and equity: it has no maturity date and its loss absorption characteristic means that rank of the perpetual sukuk is below other debts instrument. Therefore, in the event of default or bankruptcy, the debt of perpetual sukuk will only be paid off, after other debts are settled. Perpetual sukuk is attractive for both Sukuk issuer and holder for many reasons. Firstly, it is a cost-effective instrument to raise capital in a non-dilutive way, which means that it will not have a dilutive effect on the ownership percentage of existing shareholders (Collins et al., 2013). This not only increases financial flexibility but also capital adequacy. Secondly, perpetual sukuk has no maturity date and thus it is treated as equity not debt under the new Basel III regulations (Collins et al., 2013). For investors, on the other hand, perpetual sukuk typically has higher financial returns compared to conventional bond or sukuk. For these reasons, the growth of perpetual sukuk is remarkable in recent years. Many successful perpetual sukuks are being issued around the world, such as Perpetual Junior Sukuk issued by Malaysia Airlines System

International Journal of Management and Applied Research, 2019, Vol. 6, No. 2 
Berhad (MAS) and perpetual Sukuk issued by Abu Dhabi Islamic Bank (ADIB); however, there is yet to be a perpetual sukuk issued by a healthcare institute.

Mudharabah Perpetual Sukuk is an increasingly popular financial instrument across the world. Mainly, this is due to its loss absorption capacity and equity-like characteristic. Mudharabah is a trustee financing where the financier entrusts the funds to the entrepreneur, profit and loss are shared according to agreed ratio. Mudharabah perpetual sukuk can be issued to raise capital for the funding of businesses or for any shariah compliant activity. For example, Abu Dhabi Islamic Bank (ADIB) issued Mudharabah perpetual sukuk in 2012, the world's first perpetual sukuk, to raise its core capital resulted in raising US $\$ 1$ billion with the profit rate of $6.237 \%$; it was thirty times oversubscribed on the initial benchmark size, generating US $\$ 15.5$ billion (Collins et al., 2013). In 2018, ADIB raised capital through the issuance of a US\$750 million perpetual sukuk, priced at a profit rate of $7.125 \%$; the sukuk was three times oversubscribed, generating US\$2.1bn in orders (Saadi, 2018).

The development of sukuk market in Maldives is supported by the government as well as a comprehensive infrastructure such as trading and reporting system. The government established shariah advisory board and implemented a regulatory framework for sukuk issuance and investment. These government supports are important to promote sukuk issuance since different Islamic financial institutions have different stages of business cycle and levels of capacity to issue sukuk. Since 2013, Maldives Monetary Authority (MMA) started selling shariah compliant treasury bills as a result of rising demand rising from the investors for shariah compliant instruments. In the same year, Housing Development Finance Corporation (HDFC) issued the first ever corporate sukuk in Maldives and raised US\$3.9 million. To sum up, Islamic financial institutions in the country exhibit readiness to employ sukuk as a source of fund raising.

\section{Methodology}

This is a qualitative research paper that utilizes secondary data to analyse the underlying issues of healthcare system in Maldives. This paper uses official data published by the government such as National Health Plans, Budget in Statistics, laws and regulations currently applicable in Maldives. This paper also reviews industry reports, peer-reviewed research papers, newspapers, and magazine articles related to the current state of healthcare system and Islamic finance industry in Maldives.

\section{Current Status of Healthcare System of Maldives}

\subsection{Delivery of Healthcare}

The Ministry of Health is the main healthcare provider in Maldives, despite recent growth in private healthcare in the country. The Ministry of Health Maldives has been conferred Excellence in Public Health award by World Heath Organisation (WHO) due to its remarkable efforts dedicated to the health and well-being of Maldivians (WHO, 2017). The healthcare system covers all inhabited islands, while private healthcare providers and Non-Governmental Organizations (NGOs) provide services mainly in the capital city, Male'.

International Journal of Management and Applied Research, 2019, Vol. 6, No. 2 
The healthcare delivery system in the Maldives is divided into five tiers system: central, regional, atoll, sub-atoll, and island levels. However, it is not compulsory for the patients follow this pathway and they can receive healthcare service at any point. According to the Health Master Plan 2016-2025 published by Ministry of Health in 2014, there are 23 public hospitals including tertiary hospital in Male', 6 regional hospitals, 14 atoll hospitals and 172 primary healthcare centres in the country and Ministry of Health (2018) reported 198 private healthcare facilities registered under them, and over 700 NGOs. The health policies have been developed in order to provide public health facility in the form of hospital or health centre in each inhabited island while each atoll has a hospital that caters to the population of that atoll (Ministry of Health, 2014). The only exception to this policy is Kaafu atoll because the capital city Male' is located in this atoll, which has the major medical centres established by the government and private healthcare providers.

State-run pharmacies have been established in all inhabited islands, and Maldivian citizens can receive medicines on national essential drug list for free (WHO, 2017). Although this is a commendable effort made by the government, the fundamental challenges facing atoll and island communities are the relatively high per capita costs of providing healthcare services due to the fact that island populations are scattered over an immense area. The transportation problem is a major barrier to healthcare provision because it makes medical supplies and facility construction expensive to deliver. Drug prices in Maldives drug prices are 15 to 75 per cent higher than international comparators (Ministry of Finance, 2019). On top of that, logistics providers face another transportation problem: some pharmaceuticals are temperaturesensitive. Therefore, the logistics providers need to monitor temperatures and humidity for temperature-sensitive medicines and medical equipments (Papert et al., 2016), which also add costs to healthcare spending.

With a geographically dispersed nation like the Maldives, it can be difficult to reach every patient across the archipelago of over 1,000 tiny islands. The geographical dispersion of the islands leads to limited availability of skilled healthcare workforce in the smaller islands (Ministry of Health, 2014) and thus it is not uncommon for patients to travel overseas to seek medical care. On average, $66 \%$ of domestic travel between the islands was for medical purposes (Suzana et al., 2018). In order to address this matter, the government of Maldives established fully functional primary health centres in every inhabited island, backed by sea and land ambulance fleets (WHO, 2017). Additionally, air transportation is also available in case of emergency with the aid of two helicopters operated by the Indian government.

The reliance on foreign government in providing air transportation indicates the vulnerability to external economic threats and climate variability. Public infrastructure and real estate development tend to be located in the coastal zone, and thus any rise in sea level will have major impacts on safety and local economy (Mackay and Spencer, 2017). The increased regularity and intensity of storm events will also have effects on the environmental conditions and regional development in the islands. In addition to that, it is a challenge to attract and retain trained medical professionals to work in small and remote islands due to limited career development and geographical isolation (Ministry of Health, 2017).

International Journal of Management and Applied Research, 2019, Vol. 6, No. 2 
With all of these factors adding up, the healthcare needs of the island communities are not met, causing underserved rural populations to overspend on commuting and accommodation in case of medical needs. And since the developments of healthcare facilities are mainly dependent on the National Budget of the country, the government faces constrains to allocate scarce resources on healthcare.

\subsection{Financial Challenge}

The healthcare system in Maldives is funded mainly through taxation. The country has a universal health insurance scheme, Aasandha. Introduced in 2012 and revised in 2014, Aasandha provides free healthcare to all Maldivian citizens. Although healthcare is free for all citizens, a huge number of citizens choose to pay out of pocket for their medical treatments (Suzana et al., 2018) due to unavailability of specific medical treatment in the home country. More specifically, Aasandha has a comprehensive universal health care package for Maldivians which includes subsidised medical treatment abroad for healthcare services unavailable in the country (Ministry of Health, 2014). Patients can choose from a list of contracted healthcare providers in India and Sri Lanka (Suzana et al., 2018), meaning that patients would have to pay for medical treatment if they seek medical care outside these two countries. To accommodate growing patient demand and reduce the number of Maldivian travel abroad for medical care, a new public tertiary hospital (Dharumavantha Hospital) is being built (Ministry of Finance, 2019). This adds additional capital expenditure to national budget.

According to a joint publication made by Ministry of Health and World Health Organisation in 2013, nearly $50 \%$ of the healthcare expenditure was funded by household while $44 \%$ of the healthcare funds came from public funding. Table 1 illustrates sources of healthcare funds in Maldives, extracted from Ministry of Health and World Health Organisation (2013, p. 30).

Table 1: Sources of Healthcare Funds

\begin{tabular}{lrrr}
\hline Source of health funds & Amount in MVR & Amount in USD & Percentage \\
\hline Ministry of Finance and Treasury & $1,209,222,934$ & $78,419,127$ & $43.7 \%$ \\
Other Public Sources & $8,200,557$ & 531,813 & $0.3 \%$ \\
Household Funds & $1,365,372,621$ & $88,545,566$ & $49.4 \%$ \\
NGOs & $4,910,654$ & 318,460 & $0.2 \%$ \\
Employer Funds & $87,965,070$ & $5,704,609$ & $3.2 \%$ \\
Donors & $90,901,545$ & $5,895,036$ & $3.3 \%$ \\
Total & $\mathbf{2 , 7 6 6 , 5 7 3 , 2 9 0}$ & $\mathbf{1 7 9 , 4 1 4 , 6 1 0}$ & $\mathbf{1 0 0 \%}$ \\
\hline
\end{tabular}

Adapted from: Ministry of Health and World Health Organisation (2013, p. 30)

As depicted in Table 1, out-of-pocket spending is considerably high while external sources such as donations is insignificant compared to out-of-pocket spending (Ministry of Health, 2013). The "employer funds" in Table 1 refers to the amount employers contribute to the system in order to cover the health insurance of their employees. It is important to point out that the data shown on Table 1 was collected in 2011, before universal health insurance scheme was introduced by the government.

International Journal of Management and Applied Research, 2019, Vol. 6, No. 2 
The health insurance scheme is leading to a significant decline in out-of-pocket expenditure (WHO, 2017); in 2016, the out-of-pocket expenditures on healthcare in Maldives were estimated at $19.1 \%$ (World Bank, 2016).

The expenditure on healthcare is a financial constraint for both government and patients seeking medical services. The revised spending in 2018 for Aasandha and subsidies total to MVR 2,864.4 million, $43.8 \%$ higher than initial budget allocations (Ministry of Finance, 2019). The increased spending on healthcare does not necessarily results in higher operational efficiency, however. Ministry of Finance (2019, pp. 3638) reported areas of spending inefficiencies such as healthcare supply chain and management information system, which could be improved in order to reduce operational costs. Besides cost-reduction strategies, diverting government funds by implementing co-payment and premium contribution (Nagpal and Redaelli, 2013) is equally crucial in the context of broader fiscal consolidation efforts.

Based on official data given by the Ministry of Health, it can be assumed that the rise of cost within the health system is the result of a chain reaction. It begins when the government faces the challenge of providing accessible healthcare on time and in a cost-effective manner. Although the Ministry of Health has made commendable efforts in providing primary healthcare (WHO, 2017), it is difficult for rural patients seeking specialist care to receive treatment where they live. It is common for the rural populations and island communities to travel overseas to receive free medical care; however, most of the expenses occurred during the medical travel are paid out of the pocket (Suzana, et.al, 2018).

Theoretically, if the government acquire additional means to raise capital and diversify sources of income, it could create another chain reaction that may help to resolve the financial constraint faced by the government. Islamic financial instruments are viable alternatives to current healthcare financing model in Maldives because of the sociallyresponsible and risk-sharing nature of Islamic finance. There are strict rules applying to finance under Islamic law, including prohibition of exploitative interest-based loan and promote a fair return on loan by sharing profit and loss at agreed ratio. Additionally, Islamic teachings also promote creating social welfare. A wide variety of Islamic finance structures are suitable for healthcare providers. Based on a careful analysis on the available fund raising instruments, it is believed that the government of Maldives could use sukuk issuance as a means to raise capital to improve healthcare provision.

\section{Proposed Solution}

According to the literature review on current state of healthcare system in Maldives, it is clear that the government of Maldives is in need to relieve the financial strain of healthcare spending. Like many other countries, the Maldives government face the challenge of meeting rising demands of quality healthcare. However, unlike developed countries, the government of Maldives is an importer of healthcare services (Suzana, et.al, 2018) due to shortage of healthcare professionals in the rural areas. On average, $66 \%$ of the domestic travel was for medical purposes (Suzana, et.al, 2018) and the travel costs are paid out of pocket. At present, the Maldivian healthcare system is state-

International Journal of Management and Applied Research, 2019, Vol. 6, No. 2 
funded, which consume an increasing proportion of public spending annually. Although possible revenue sources for the universal healthcare insurance have been proposed (Nagpal and Redaelli, 2013), the healthcare system in the country primarily relies on public funding.

In long run, public funding is unlikely to be sufficient to keep pace with the projected increase in healthcare demand and medical need, which is being driven rising expectations. Beneficiaries of Aasandha tend to over-utilize public healthcare services and misconceive Aasandha as an "unlimited pre-paid scheme" (Ministry of Health, 2014, p. 17), which cause inefficient use of limited resources. One major problem of free healthcare is an excess of demand over supply, which often results in long waiting list and shortage of hospital beds. Fee-for-service payment mechanism, on the other hand, incentivises the service providers to create artificial demand and potentially leads to escalating healthcare costs (Nagpal and Redaelli, 2013).

Thus, in the authors' opinion, the government of Maldives should consider multiple sources of revenue and alternative source of capital to finance healthcare. Revenue generating activities like co-payment and premium contribution (Nagpal and Redaelli, 2013) may help to offset healthcare expenditure in short and medium term, but it does not address the financial constraint of funding healthcare in long run. Considering the success of Vaccine Sukuk (Bennett, 2015; Vizcaino, 2014), sukuk issuance appears to be a viable option for healthcare providers to raise capital.

The key enablers of facilitating the use of Islamic financial instruments in healthcare financing are supportive government and the existence of the appropriate Islamic financial ecosystem as well as a level of acceptability and readiness by bankers to employ them in healthcare financing. Since the establishment of Maldives Islamic Bank (MIB) on 7th March 2011, the first full-fledged Islamic Bank in Maldives, the Islamic finance industry in the country has been growing steadily. There is a ready market for trading in Maldives and the country has strong debt affordability metrics because of a well-funded banking system and a large revenue base (Moody's Investors Service, 2017).

\subsection{Proposed Transaction Parties for Mudharabah Perpetual Sukuk}

\section{Obligor \& Mudarib- Ministry of Health}

In accordance with the terms of the Restricted Mudharabah Agreement signed between the Mudarib and Rabb-ul-Maal, it is recommended that Ministry of Health to be the Mudarib and utilise the Mudharabah Assets to conduct shariah compliant businesses, including primary healthcare facilities, regional hospitals, and tertiary hospitals in Maldives. The Mudharabah Assets will be limited to medical equipment in order not to violate shariah principles.

\section{Issuer, Trustee \& Rabb-ul-Maal - Hazana Maldives Limited}

Hazana Maldives Limited is a government finance company specialises in Islamic investment funds. Established in 2016, Hazana acts as a Special Purpose Vehicle (SPV) to aid the government in raising capital through Islamic finance instruments. Therefore, it is believed that Hazana is suitable for the role of issuer, trustee and Rabbul-Maal.

International Journal of Management and Applied Research, 2019, Vol. 6, No. 2 


\section{Sukukholders}

The proposed Perpetual Sukuk will cater to three main types of investors:

- Tier 1 Investors: These investors will be the Institutional Investors (e.g. Maldives Islamic Bank, Bank of Maldives Islamic, Ayady Takaful, or Amana Takaful). Any investment by Tier 1 investors will be secured thus will be considered a senior debt of the Issuer. Hence, in case of a default, their investment will be paid back first before other debts. The minimum investment for Tier 1 investors is set at MVR 5 million. No maximum investment is set for Tier 1 investors.

- Tier 2 Investors: These will be retail investors (i.e. general public, including high net worth individuals) who interested in sukuk investment. Minimum investment for Tier 2 investors is MVR 5,000 in the issuance, with MVR 500,000 set as the maximum investment per investor.

- Tier 3 Investors: These will be foreign investors interested in sukuk investment. It is likely that Tier 3 investors invest in foreign currency and thus there may be foreign exchange risk at the time of profit distribution. For this reason, a forward contract will be signed between Tier 3 investors and the Trustee, Hazana Maldives Limited, setting an agreed exchange rate which will be utilised at the time of periodic profit payment and/or redemption payment. Minimum investment for Tier 3 investors is set at USD 50,000 with USD 1 million set as maximum investment per investor.

\subsection{Mudharabah Perpetual Sukuk Structure}

The proposed model is structured as below:

1. Issuances of Mudharabah Sukuk

On the Issue Date as agreed between the Obligor and the Issuer -- Hazana Maldives Limited -- will issue Mudharabah Sukuk certificates to investors.

2. Declaration of Trust

Trust will be declared between the Investors and Hazana Maldives Limited as the Trustee. The Trust will be declared in favour of the Sukukholders to ensure the protection of their rights throughout the tenure of the Sukuk.

3. Master Restricted Mudharabah Agreement

A Restricted Mudharabah Partnership Agreement will be signed between Hazana Maldives Limited as the Rabb-ul-Maal and Ministry of Health as the Mudarib. This agreement will outline the restrictions of the Mudharabah agreement including other terms and conditions of the partnership. Under this agreement, Ministry of Health will utilize the Mudharabah Assets to conduct Shariah compliant businesses which are to be operated by public hospitals and healthcare facilities:

3.1 With the establishment of the Mudharabah agreement, the Mudarbah capital will be raised through Sukuk issuance and transfer to Mudarib. This capital will then be transferred to the relevant hospitals in order to acquire necessary equipments.

International Journal of Management and Applied Research, 2019, Vol. 6, No. 2 
4. Periodic Profit Payment

Mudharabah Profit Payments will be acquired by Ministry of Health and paid to Hazana Maldives Limited who will distribute them to the Sukukholders on periodic basis outlined in the Prospectus of the issuance.

5. Liquidation Proceeds

Subject to conditions outlined in the Prospect of the issuance, Ministry of Health, as their capacity as Mudarib may liquidate the Mudharabah portfolio in whole. These conditions may include the following:

- On the First Call Date or any Mudharabah Profit Distribution after the First Call Date

- Any date on or after the date of the Mudharabah Agreement upon the occurrence of either a Tax Event or a Capital Event, as defined in the Prospectus of the Issuance

The proposed Mudharabah perpetual sukuk is illustrated in Figure 1.

Figure 1: Proposed Perpetual Sukuk Mudharabah

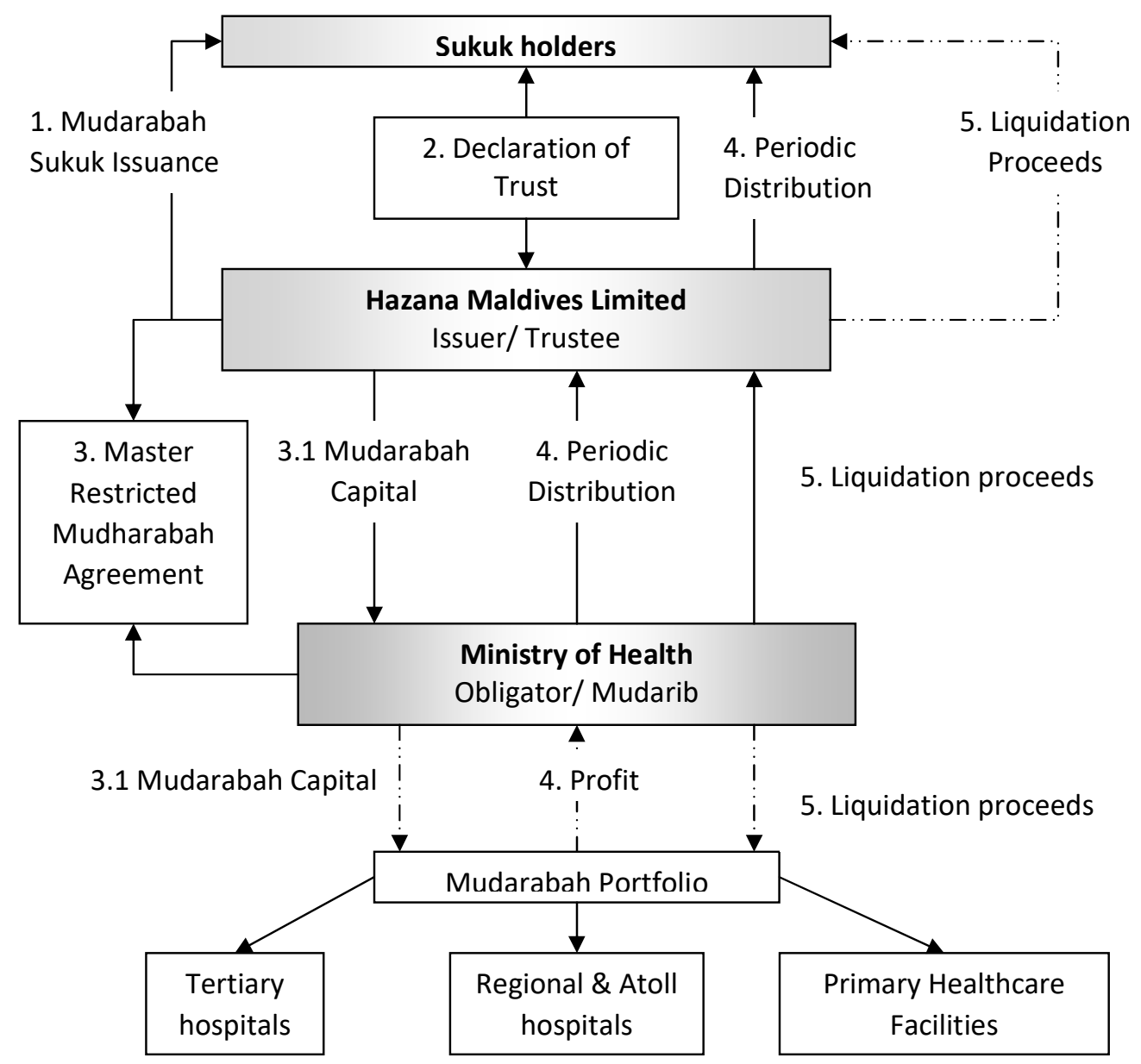

International Journal of Management and Applied Research, 2019, Vol. 6, No. 2 


\subsection{Salient Features of the Mudharabah Perpetual Sukuk Structure}

\subsubsection{Limited Recourse}

Under the Mudharabah Perpetual Sukuk, each Sukuk Certificate will be issued to the sukukholders represents an undivided ownership interest in the Mudharabah Assets. This means that no payment of any amount shall be made in respect of the Sukuk Certificates. It will be stipulated in the prospectus that Sukukholders have no recourse to any assets of the Trustee, and/or its directors or officers in their capacity as such, other than the relevant Mudharabah Assets.

\subsubsection{Redemption and/or liquidation}

There will be no fixed redemption date for the proposed Mudharabah Perpetual Sukuk. This means that redemption of the Sukuk will only be conducted if a winding-up, dissolution or liquidation event outlined in the prospectus occurs.

Similarly, as mentioned in step 5 of section 5.2 above, Ministry of Health as Mudarib may liquidate the Mudharabah portfolio in whole. In order to carry out the liquidation, the Ministry would instruct Hazana Maldives Limited as the Trustee to provide proper notice to the Sukukholders in order to carry out the process as outlined in the prospect of the issuance. Similarly, in a Tax Event or a Capital Event, the Sukuk can be redeemed as well. A Capital Event arises when the Mudarib is notified by the regulator(s) that the Sukuk Certificates will cease or have ceased to qualify for inclusion in full in the consolidated Tier 1 Capital of the Mudarib. A Tax Event arises if the Mudarib or the Rabb-ul-Maal would, as a result of change in Tax Law, is required to pay additional amounts which cannot be avoided when making the next Mudharabah profit payment. All such events will be further detailed in the prospectus to ensure that investors are well informed.

\section{Current Regulatory Framework}

Prior to the issuance of the first Sukuk in Maldives in September 2013 by Housing Development Finance Corporation (HDFC), the Capital Market Development Authority (CMDA) has set out several regulations and guidelines in order to ensure the proper governance of Sukuk issuances in the market. Any Sukuk issuances must be in compliance with the following Acts:

i. Maldives Companies Act (Law Number:10/1996)

ii. Maldives Securities Act (Law Number: 2/2006)

iii. Regulations on Issuance of Securities 2011

iv. Regulations on Issuance of Sukuks

v. Securities (Continuing Disclosure Obligations of Issuers) Regulations 2010 and the First Amendment

vi. Approved concepts \& principles for the purpose of Structuring, Documenting and Trading of Sharia Compliant Securities

vii. Regulation on Shariah Screening of Equity Securities

viii. $\quad$ Listing Rules (Effective from 21st December 2015)

ix. Minimum Quarterly Reporting Requirement for Listed Companies

x. Fit \& Proper Guidelines for Director of Listed Companies

International Journal of Management and Applied Research, 2019, Vol. 6, No. 2 


\subsection{Challenges in the Current Regulatory Framework}

6.1.1. Inability to Reach Public Investors

As per Clause 23 (a) of the Maldives Companies Act, "companies other than those registered under this Act as public companies shall not sell shares or debentures to the public". The Act further defines that sales of shares and debentures to the public means that "the company's share and debentures may be purchased by any person of the public and that the shares and debentures of the company are freely transferrable from one person to another without the approval of the Company".

Therefore, as per the current regulation, in order to issue a Sukuk to which the public can invest in, Companies would need to be made Public and listed at the Maldives Stock Exchange (as per the guidelines underlined by the Companies Act and guidelines issued by CMDA in relation to listed companies). If a private Company wishes to issue a Sukuk, they can only issue it under Private Placement where only invited institutional investors will be allowed to purchase Sukuk certificates. This means that, unless the Mudharabah Perpetual Sukuk is issued as a sovereign issuance, or listed in the Stock Exchange, institutional investor in Maldives like Maldives Pension Administration Office (MPAO) will not be able to invest in this instrument.

Moreover, foreign investors need to comply with the Law on Foreign Investments in the Republic of Maldives (Law Number: 25/79) and the company they invest in to be in compliance with the said Law as well. This adds barriers for the proposed sukuk to reach global investors.

\subsubsection{Special Purpose Vehicle}

Under the proposed structure, Hazana Maldives Limited is recommended to be the SPV of the issuance since it has been established by the Government with the mandate to be the SPV for the Government. Hazana Maldives Limited is a private company registered at Ministry of Economic Development, with their 100\% shareholders being the government of Maldives.

The greatest challenge of using Hazana Maldives as the SPV is that there is no specific SPV guideline or regulation in Maldives, thus the company has to comply with the Companies Act of Maldives which requires the Company to have a paid up capital, annual fees, definite number of Board Directors and management and pay taxes, which could affect the profitability of Sukuk.

Another challenge of using Hazana Maldives as the SPV of the proposed solution is that, foreign investors would need to follow the Law on Foreign Investments in the Republic of Maldives (Law Number: 25/79) which may require the company in which they invest in to be a Foreign Direct Investment Company.

Thus, while the setup has been put forth with the establishment of Hazana Maldives, there are certain areas that need to be addressed in the regulatory framework to address certain matters and risks that may arise with the Sukuk issuance under a private company.

International Journal of Management and Applied Research, 2019, Vol. 6, No. 2 


\subsection{Proposed Solutions to Address Challenges in the Current Regulatory Framework}

6.2.1. Special Purpose Vehicle as a Public Listed Company

As stipulated in the Maldives Companies Act, the best solution to address matters outlined in the previous section is to convert Hazana Maldives Limited into a Public Listed Company. This would allow the Company to issue shares and debentures to the public without restrictions from the current regulatory framework.

In order to convert the Company as a Public Listed Company, Hazana Maldives Limited would need to comply with "The Listing Rules of Maldives Stock Exchange" which as been effective since $21^{\text {st }}$ December 2015 by CMDA which includes an Initial Listing Application. Under this process, the Company would be required to issue a prospectus that complies with the prospectus requirement of the Maldives Companies Act and any additional regulation which would need to acquire approval from CMDA as well as the Registrar of the Companies (CMDA, 2018). The Company's Memorandum and Articles of Association would need to be amended accordingly as well along with the appointment of at least ten shareholders (The Companies Act of the Republic of Maldives).

\subsubsection{Special Purpose Vehicle as a subsidiary of Maldives Monetary Authority (MMA)}

Under the Maldives Monetary Authority Act (MMA) of 1981, one of the functions of the MMA has the authority to act as the agent to issue securities on behalf of the government. Under this mandate, MMA currently offers conventional as well as Islamic Securities such as Mudharabah Certificate, Murabahah Certificate, Wakalah Bi Al-Istithmar Certificate as well as Murabahah Sukuk.

In other jurisdictions like Malaysia, the Central Bank has their own SPV in order to issue Sovereign Sukuks. For example, the central bank of Malaysia, Bank Negara Malaysia (BNM) established an SPV -- BNM Sukuk Berhad -- in order to issue Sukuk Bank Negara Malaysia in 2006 (Bank Negara Malaysia, 2006). This company is established under Cagamas Holdings Berhad which is a subsidiary of BNM established as the National Mortgage Corporation of Malaysia.

Following this concept, Hazana Maldives Limited can be converted as a subsidiary of MMA that conducts the role of SPV for the government with MMA taking on the oversight function. This also gives any issuance of Hazana Maldives Limited the status of sovereign issuances which allows organisation like MPAO to invest in Sukuk even if it is not listed in the Stock Exchange.

\subsubsection{Establish regulation to list individual Securities in Stock Exchange}

Currently, only public listed companies are allowed to issue equity and debt securities including Sukuks in the Stock Exchange under the Listing Guidelines issued by CMDA and no regulation provides guidelines for private companies to issue equity or debt securities in the stock exchange. If companies are able to meet the rigid criteria and comply with the relevant regulations published by the regulatory authority, it would allow companies such as Hazana Maldives Limited to issue securities for the

International Journal of Management and Applied Research, 2019, Vol. 6, No. 2 
government without incurring any additional cost that would rise when converting to a public listed company.

\section{Conclusion}

As a developing country, Maldives is undergoing steady growth in several areas including the healthcare sector. However, the geographical challenges would always remain an issue that needs to be addressed by local authorities when it comes to delivering healthcare services to inhabited islands in Maldives. And in the authors' opinion, the best way for this would be to diversify source of funding. To be efficient and sustainable in the context of healthcare provision, healthcare reform requires enormous financial resources and supportive government. It is hoped that the outcome of this paper will provide an insight to policy makers on healthcare financing and consider Islamic financial instruments as alternative sources of funding. The introduction of perpetual sukuk in Maldives will open a new chapter in the domestic Islamic finance industry and promote the creation of innovative Islamic financial structures in the country.

As a hundred percent Muslim country, the Islamic finance industry in Maldives is growing steadily. Instead of depending on foreign support or aid to develop the health sector, it is believed that introduction of the proposed perpetual sukuk will help to mobilise fund to enhance healthcare services in Maldives. It is hoped that the proposed perpetual sukuk could assist the government to improve healthcare industry without over relying on public funding or foreign aid.

\section{References}

1. Accounting and Auditing Organization for Islamic Financial Institutions (AAOIFI) (2008), Financial Accounting Standards, Accounting and Auditing Organization for Islamic Financial Institutions, Bahrain, AAOFII.

2. Bank Negara Malaysia (2006), Issuance of Sukuk Bank Negara Malaysia based on Ijarah concept. [Online] available from:

http://www.bnm.gov.my/index.php?ch=en press\&pg=en press\&ac=841\&lang=en [21 March 2019].

3. Bennett, M. (2015), "Vaccine Sukuks: Islamic securities deliver economic and social returns", World Bank, [Online] available from: https://blogs.worldbank.org/arabvoices/vaccine-sukuks-islamic-securities-delivereconomic-and-social-returns [Accessed on 24 June 2019].

4. Capital Market Development Authority (CMDA) (2018), A Guide to Going Public and Issuing Securities in the Maldives Securities Market [Online] available from: https://www.cmda.gov.mv/assets/Going-Public/Going-Public-Package-Full290418-Final.pdf [Accessed on 24 March 2019].

5. Collins, N.; Irvine, L. and Gaskin, R. L. (2013), “Abu Dhabi Islamic Bank leads the way with the world's first Basel III compliant Tier 1 Sukuk issuance", Islamic Finance News, [Online] available from: 
https://www.lw.com/thoughtLeadership/abu-dhabi-islamic-bank-leads-way [Accessed on 24 June 2019].

6. The Companies Act of the Republic of Maldives, Act No: 10/96

7. Ismath Bacha, O and Mirakhor, A. (2019), Islamic Capital Markets: A Comparative Approach. $2^{\text {nd }}$ Edition. Singapore: World Scientific Publishing Co. Ltd;

8. Lahsasna, A. and Hassan, K. M. and Ahmad, R. (2018), Forward Lease Sukuk in Islamic Capital Markets, Switzerland: Palgrave Macmillan. https://doi.org/10.1007/978-3-319-94262-9

9. Law on Foreign Investments in the Republic of Maldives (Law Number: 25/79)

10. Mackay, E. and Spencer, A. (2017), "The future of Caribbean tourism: competition and climate change implications", Worldwide Hospitality and Tourism Themes, Vol. 9 No. 1, pp. 44-59. https://doi.org/10.1108/WHATT-11-2016-0069

11. Maldives Monetary Authority Act 1981

12. Ministry of Finance (2019), Budget in Statistics 2019, [Online] Available from: http://www.budget.gov.mv/en/downloads/BudgetBook.php [Accessed on19 March 2019].

13. Ministry of Health and World Health Organization (2013), Maldives National Health Accounts 2011, joint publication of Ministry of Health and World Health Organization [Online] Available from:

http://www.health.gov.mv/Uploads/Downloads/Informations//Informations(61).pdf [Accessed on19 March 2019].

14. Ministry of Health (2014), Health Masters Plan 2016 - 2025. [Online] Available from:

http://www.health.gov.mv/Uploads/Downloads//Informations/Informations(42).pdf [Accessed on19 March 2019].

15. Ministry of Health (2018), Private Health Facilities Registered under Ministry of Health. [Online] Available from:

http://www.health.gov.mv/Uploads/Downloads/Informations//Informations(126).p df [Accessed on19 March 2019]

16. Moody's Investors Service (2017), Moody's: Maldives' credit profile balances healthy GDP growth with an anticipated ramp-up in debt, [Online] Available from: https://www.moodys.com/research/Moodys-Maldives-credit-profilebalances-healthy-GDP-growth-with-an--PR_373259 [Accessed on 20 March 2019].

17. Nagpal, S. and Redaelli, S. (2013), Health expenditure, equity and evolution of Aasandha: Maldives health policy note no. 2. Washington DC: World Bank. [Online] Available from: http://documents.worldbank.org/curated/en/884371468050349732/Healthexpenditure-equity-and-evolution-of-Aasandha [Accessed on19 March 2019].

18. Papert, M., Rimpler, P. and Pflaum, A. (2016), "Enhancing supply chain visibility in a pharmaceutical supply chain", International Journal of Physical Distribution

International Journal of Management and Applied Research, 2019, Vol. 6, No. 2 
\& Logistics Management, Vol. 46, No. 9, pp. 859-884.

https://doi.org/10.1108/IJPDLM-06-2016-0151

19. Saadi, D. (2018), “ADIB raises Dh1bn through rights issue and closes $\$ 750 \mathrm{~m}$ sukuk", The National, [Online] Available from:

https://www.thenational.ae/business/banking/adib-raises-dh1bn-through-rightsissue-and-closes-750m-sukuk-1.779182 [Accessed on 31 July 2019].

20. Suzana, M.; Walls, H.; Smith, R. and Hanefeld, J. (2018), "Understanding medical travel from a source country perspective: a cross sectional study of the experiences of medical travellers from the Maldives", Globalization and Health, Vol. 14, No. 58. https://doi.org/10.1186/s12992-018-0375-4

21. World Bank (2018), The World Bank in Maldives [Online] Available from: https://www.worldbank.org/en/country/maldives/overview [Accessed on 31 July 2019].

22. World Bank (2016), Out-of-pocket expenditure (\% of current health expenditure) [Online] Available from:

https://data.worldbank.org/indicator/SH.XPD.OOPC.CH.ZS [Accessed on 31 July 2019].

23. World Health Organisation (2017), Ministry of Health Maldives gets WHO Excellence in Public Health Award, [Online] Available from: http://www.searo.who.int/mediacentre/releases/2017/1659/en/ [Accessed on 31 July 2019].

24. Vizcaino, B. (2014), "Sukuk for vaccine fund ushers Islamic finance into ethical sphere", Reuters, [Online] Available from: https://www.reuters.com/article/ukiffim-sukuk/sukuk-for-vaccine-fund-ushers-islamic-finance-into-ethical-sphereidUKKCNOJJ0MX20141205 [Accessed on 31 July 2019].

International Journal of Management and Applied Research, 2019, Vol. 6, No. 2 